\title{
Impact of Parsley Extract on Experimental Rats with Kidney Stones and using it to make some food products
}

\author{
Dina Hamed EL Bushuty *Ola Talaat Sahloul * Eman Ebrahim Abdel-Halim
}

*Home Economics Dept., Fac. of Specific Education, Damietta Univ., Egypt.

\begin{abstract}
Parsley is a rich source of natural antioxidants. The current study aims to study the impact of aquas extract of parsley cultivated in Egypt on experimental rats with kidney stones then using it to make some products. Biochemical analysis and histopathological properties were investigated using forty eight male albino rats which divided into two main groups, the first: control group (P) fed on basal diet, while the second was fed on basal diet and Ethylene glycol and ammonium chloride for 30 days to induce urolithiasis, Then divided to 5 subgroups, positive control(pc)fed on basal diet, the others were divided into four groups $(\mathrm{P} 1, \mathrm{P} 3)$ fed on basal diet plus $5 \%, 10 \%$ of aques extract of parsley seeds, respectively, (P2,P4) Fed on basal diet plus 5\%, 10\% of aques extract of parsley leaves respectively. Also, prepared 5 products (Ice cream, Eggplant salad, Crème bavaroise, Russian salad and Tuna salad )using aques extract of parsley leaves, and seeds. The results showed significant decrease in treated groups in serum urea, creatinine, uric acid and electrolytes. Also, declared that parsley has a nephroprotective and antiurolithiatic effects. According to sensory evaluation of all products revealed non- significant decrease in $(p<0.05)$ in color, texture, odor, taste and general acceptability. concerning histopathological studies' results declared that good effects on kidney and liver.
\end{abstract}

Keywords: parsley-leaves-seeds-extract-rats-kidney stones.

This research was extracted from Thesis master degree under title: Using arsley in the Making of Food Products and Studying its Effect on Experimental Rats Infected with Kidney Stones, to Demonstrator: Eman Ebrahim Abdel-Halim Ebrahim Al-saeed. 


\section{INTRODUCTION}

Kidney filter blood from poisonous, also removing waste and extra water from the body in the forme of urine. Functional damage to the kidney can lead to a variety of syndromes, including kidney failure and kidney stones (European Food Safety Authority., 2010 and Zahid et al.,2013).

Urolithiasis is the third most common disorder of urinary system, in rates of $50 \%$ in ages of $5-10$ year and $75 \%$ in 20 year old. Furthermore $12 \%$ of world population have a renal stone disease in rates of $70-80 \%$ in males and $47-60 \%$ in females (Moe.,2006 and Soundararajan et al.,2006).

On the other hand, $80 \%$ of stones are composed of calcium oxalate and calcium phosphate, $(10 \%, 9 \%$, and $1 \%)$ of struvite, uric acid and cystine or ammonium acid urate, respectively (Devi et al.,2015).

Medicinal plants and herbs play an important role in the prevention and treatment of kidney diseases, with regard to petroselinum sativum (PS) or parsley is an antioxidant, anti-inflammatory, antiedema antihypertensive , antidiabetic, antimicrobial and reconstruct kidney tissue after nephrotoxicity (Kreydiyyeh and Usta ., 2002 and Wahba et al .,2009)

Parsley leaves are rich in apigenin and its glucosidal flavonoids that were found to possess anti-inflammatory especially for renal inflammation; antioxidant and anticancer activities (Dorman et al., 2011 and Papay et al., 2012).

Parsley also used as a medicinal herb and domestic medicine, and therefore used as a diuretic where it is useful in elimination the body of stones, also helps bodies to remove toxins via the urine and treatment of various diseases (Sarwar et al., 2016).

The aqueous extract of parsley reduced the number of calcium oxalate deposits and therefore parsley can be used for kidney and bladder stones (Saeidi et al., 2012).

Moreover, parsley is widely used. leaf of parsley is used often as a garnish. Its fresh and dried leaves are commonly used in cooking (Meyer.,1998 and Azeez and Parthasarathy, 2008).

This study aims to illustrate the impact of parsley extract on experimental rat with kidney stones then using it in some food products. 


\section{MATERIALS AND METHODS}

\section{Materials:}

\section{1-Parsley seeds and leaves:}

Parsley seeds were obtained from a local vegetable store, Cairo, Egypt.

\section{2- Chemicals and Kits:}

Vitamins, minerals, cellulose, choline chloride, diagnostic kits and ethylene glycol and ammonium chloride were obtained from Elgomhoria Company, Cairo , Egypt.

\section{Methods:}

\section{Extract preparation:}

Parsley extracts were prepared fresh at the beginning of every experiment and always from the same batch.

(A)Aquas extract of parsley seeds : $(5 \mathrm{~g})$ of parsley seeds were soaked in $(95 \mathrm{ml})$ water and $(10 \mathrm{~g})$ of parsley seeds soaked in $(90 \mathrm{ml})$ water for $1 \mathrm{~h}$ at room and the suspension then decanted, filtered through Whatman filter paper no. 1 and the filtrate was used in the preparation of the different perfusion buffers according to Kreydiyyeh and Usta, (2002 ).

(B) Aquas extract of parsley leaves: $(5 \mathrm{~g})$ of fresh leaves of parsley were mixed with $(95 \mathrm{ml})$ boiling water and $(10 \mathrm{~g})$ of fresh leaves of parsley were mixed with $(90 \mathrm{ml})$ boiling water and steeped in boiled water in aclosed vessel for 10 minute. The fresh prepared extract has been filtered using piece of gauze according to Alzergy et al., (2018).

\section{Experimental design}

Male albino rats Sprague Dawley Strain (48 rats) weighting (about $180 \mathrm{~g}$ ) was kept in individual stainless steel cages under hygienic conditions and fed one week on basal diet for adaptation. The experiment on rats was carried out according to the National regulations on animal welfare and Institutional Animal Ethical Committee according to Reeves et al., (1993).

After the period of adaptation on basal diet (one week), the rats were divided into two main groups as follows : 
The first main groups (8 rats): were fed on basal diet and tap drinking water (as a control negative group).

The second main group (40 rats ): were fed on basal diet and were received Ethylene glycol (EG) $(0.75 \% \mathrm{v} / \mathrm{v})$ and ammonium chloride( $\mathrm{AC})(1 \%$ $\mathrm{w} / \mathrm{v}$ ) in drinking water ad libitum for 30 days according to Fan et al., (1999) With modification ethylene glycol (EG) plus ammonium chloride (AC) were used to induce urolithiasis.

After 30 days of the experiment, the increase of urea, uric acid and creatinine in the blood was confirmed kidney stones were formed in the second main group. The rats in the second main group were divided into five subgroups $(\mathrm{n}=8)$.

PC (Positive control):Fed on basal diet as apositive control group and was received ethylene glycol (EG) $(0.75 \% \mathrm{v} / \mathrm{v})$ and ammonium chloride( $\mathrm{AC})$ $(1 \% \mathrm{w} / \mathrm{v})$ in drinking water ad libitum .

P1:Fed on basal diet and treated with $5 \%$ of aques extract of parsley seeds.

P2: Fed on basal diet and treated with $5 \%$ of aques extract of parsley leaves.

P3: Fed on basal diet and treated with $10 \%$ of the aques extract of parsley seeds.

P4: Fed on basal diet and treated with $10 \%$ of aques extract of parsley leaves.

\section{Biological Determination}

During the experimental period (75 days), the quantities of diet, which were consumed and / or wasted, were recorded every day in order to determine feed intake of each group. In addition, rat's weight was recorded weekly, to determine body weight gain \% according to Chapman et al., (1959) .

\section{Biological Analysis of blood serum:}

At the end of experiment period, the rats were fasted overnight then the rats were anaesthetized and sacrificed, and blood samples were collected from the aorta. The blood samples were centrifuged for 10 minutes at $3000 \mathrm{rpm}$ to separate the serum. The serum was carefully separated into dry clean Wasserman tubes by using a Pasteur pipette and kept frozen until analysis at $20^{\circ} \mathrm{C}$ according to the method described by Drury and Wallington, (1980). 
Determination of serum sodium and potassium was determined according to Gumaih et al., (2017). Serum calcium were measured with auto analyzer (BT3000) according to Hadjzadeh et al., (2007). Serum chloride was determined according to Gumaih et al., (2017). Serum creatinine was determined according to the method described by Bohmer, (1971). Serum uric acid was determined by Fossati et al., (1980) .Serum urea was determined according to the method described by Patton and Crouch, (1977).

\section{Biological Analysis of urine:}

All animals were fasted overnight then urine samples were collected from each rat at the first and last days, before and after treatment respectively. These animals were kept in individual metaboli cages, urine samples of $24 \mathrm{~h}$ were collected and drops of concentrated hydrochloric acid was added to the urine samples to analyze calcium and protein.

Urine calcium was determined according to the method described by Werness et al., (1985) and urine protein was determined according to Gumaih et al ., (2017).

\section{Histopathological Examination}

Specimens from kidney and liver were taken immediately after sacrificing animals, and fixed in $10 \%$ buffered neutral formalin solution. The fixed specimens were then trimmed, washed and dehydrated imbedded in paraffin, cut in sections of 46 microns thickness and stained with haematoxylin and eosin stain, according to Sheenan and Hrapchak, (1980).

\section{Composition of food products}

Ingredients and methods according to Andreasen and Nielsen, (1992) Saba,(2001).

Table (1): Ingredients of food products

\begin{tabular}{|c|c|c|c|c|}
\hline \multicolumn{5}{|c|}{ Ice cream } \\
\hline $\begin{array}{c}\text { Aques } \\
\text { extract of } \\
\text { Parsley } 0 \%\end{array}$ & $\begin{array}{c}\text { Aques } \\
\text { extract of } \\
\text { Parsley } \\
\text { seeds 5\% }\end{array}$ & $\begin{array}{c}\text { Aques } \\
\text { extract of } \\
\text { Parsley } \\
\text { leaves5\% }\end{array}$ & $\begin{array}{c}\text { Aques extract } \\
\text { of Parsley } \\
\text { seeds } 10 \%\end{array}$ & $\begin{array}{l}\text { Aques extract } \\
\text { of Parsley } \\
\text { leaves } 10 \%\end{array}$ \\
\hline $\begin{array}{l}\text { Frozen } \\
\text { Strawberry: } 15 \\
0 \mathrm{~g} \\
\text { Suger powder } \\
: 20 \mathrm{~g}\end{array}$ & $\begin{array}{l}\text { Frozen } \\
\text { Strawberry:1 } \\
50 \mathrm{~g} \\
\text { Sugerpowder } \\
: 20 \mathrm{~g} \text { Aques } \\
\text { extract of } \\
\text { Parsley seeds } \\
5 \%\end{array}$ & $\begin{array}{l}\text { Frozen } \\
\text { Strawberry: } 15 \\
0 \mathrm{~g} \text { Suger } \\
\text { powder :20g } \\
\text { Aques extract } \\
\text { of Parsley } \\
\text { leaves } 5 \%\end{array}$ & $\begin{array}{l}\text { Frozen } \\
\text { Strawberry: } 150 \\
\mathrm{~g} \text { Suger } \\
\text { powder }: 20 \mathrm{~g} \\
\text { Aques extract } \\
\text { of Parsley seeds } \\
10 \%\end{array}$ & $\begin{array}{l}\text { Frozen } \\
\text { Strawberry: } 150 \mathrm{~g} \\
\text { Suger } \\
\text { powder: } 20 \mathrm{~g} \\
\text { Aques extract of } \\
\text { Parsley leaves } 10 \\
\%\end{array}$ \\
\hline
\end{tabular}




\begin{tabular}{|c|c|c|c|c|}
\hline \multicolumn{5}{|c|}{ Egg plant salad } \\
\hline $\begin{array}{l}\text { Aques extract of } \\
\text { Parsley 0\% }\end{array}$ & $\begin{array}{c}\text { Aques } \\
\text { extract of } \\
\text { Parsley } \\
\text { seeds 5\% } \\
\end{array}$ & $\begin{array}{c}\text { Aques extract o } \\
\text { Parsley } \\
\text { leaves5\% }\end{array}$ & $\begin{array}{c}\text { Aques extract } \\
\text { of Parsley } \\
\text { seeds } 10 \%\end{array}$ & $\begin{array}{c}\text { Aques } \\
\text { extract of } \\
\text { Parsley } \\
\text { leaves } 10 \%\end{array}$ \\
\hline $\begin{array}{l}\text { eggplant:200g } \\
\text { Minced } \\
\text { garlic: } 15 \mathrm{~g}\end{array}$ & $\begin{array}{l}\text { eggplant:20 } \\
0 \mathrm{~g} \\
\text { Minced } \\
\text { garlic: } 15 \mathrm{~g} \\
\text { Aques } \\
\text { extract of } \\
\text { Parsley } \\
\text { seeds 5\% }\end{array}$ & $\begin{array}{l}\text { eggplant: } 200 \mathrm{~g} \\
\text { Minced } \\
\text { garlic: } 15 \mathrm{~g} \\
\text { Aques extract of } \\
\text { Parsley } \\
\text { leaves } 5 \%\end{array}$ & $\begin{array}{l}\text { eggplant: } 200 \mathrm{~g} \\
\text { Minced } \\
\text { garlic: } 15 \mathrm{~g} \\
\text { Aques extract } \\
\text { of Parsley } \\
\text { seeds } 10 \%\end{array}$ & $\begin{array}{l}\text { eggplant: } 20 \\
0 \mathrm{~g} \text { Minced } \\
\text { garlic: } 15 \mathrm{~g} \\
\text { Aques } \\
\text { extract of } \\
\text { Parsley } \\
\text { leaves } 10 \%\end{array}$ \\
\hline \multicolumn{5}{|c|}{ Crème Bavaroise } \\
\hline $\begin{array}{c}\text { Aques } \\
\text { extract of } \\
\text { Parsley } 0 \%\end{array}$ & $\begin{array}{l}\text { Aques extract of } \\
\text { Parsley seeds 5\% }\end{array}$ & $\begin{array}{c}\text { Aques extract } \\
\text { of Parsley } \\
\text { leaves } 5 \%\end{array}$ & $\begin{array}{c}\text { Aques } \\
\text { extract of } \\
\text { Parsley } \\
\text { seeds } 10 \%\end{array}$ & $\begin{array}{c}\text { Aques } \\
\text { extract of } \\
\text { Parsley } \\
\text { leaves } 10 \%\end{array}$ \\
\hline $\begin{array}{l}\text { Strawberry } \\
\text { juice : } 150 \mathrm{~g} \\
\text { whipped } \\
\text { cream:50g } \\
\text { sugar:50g } \\
\text { Gelatin:50g }\end{array}$ & $\begin{array}{l}\text { Strawberry juice } \\
: 150 \mathrm{~g} \\
\text { whipped cream } \\
: 50 \mathrm{~g} \\
\text { sugar:50g } \\
\text { Gelatin:50g } \\
\text { Aques extract of } \\
\text { Parsley seeds 5\% }\end{array}$ & $\begin{array}{l}\text { Strawberry juice } \\
: 150 \mathrm{~g} \\
\text { whipped } \\
\text { cream:50g } \\
\text { sugar: } 50 \mathrm{~g} \\
\text { Gelatin:50g } \\
\text { Aques extract of } \\
\text { Parsley leaves } \\
5 \%\end{array}$ & $\begin{array}{l}\text { Strawberryju } \\
\text { ice }: 150 \mathrm{~g} \\
\text { whipped } \\
\text { cream:50g } \\
\text { sugar:50g } \\
\text { Gelatin:50g } \\
\text { Aques } \\
\text { extract of } \\
\text { Parsley seeds } \\
10 \%\end{array}$ & $\begin{array}{l}\text { Strawberry } \\
\text { juice }: 150 \mathrm{~g} \\
\text { whipped } \\
\text { cream50g } \\
\text { sugar:50g } \\
\text { Gelatin:50g } \\
\text { Aques } \\
\text { extract of } \\
\text { Parsley } \\
\text { leaves } 10 \%\end{array}$ \\
\hline \multicolumn{5}{|c|}{ Russian salad } \\
\hline $\begin{array}{c}\text { Aques } \\
\text { extract of } \\
\text { Parsley } 0 \%\end{array}$ & $\begin{array}{c}\text { Aques extract } \\
\text { of Parsley } \\
\text { seeds } 5 \%\end{array}$ & $\begin{array}{c}\text { Aques extract } \\
\text { of Parsley } \\
\text { leaves 5\% }\end{array}$ & $\begin{array}{l}\text { Aques extract } \\
\text { of Parsley } \\
\text { seeds } 10 \%\end{array}$ & $\begin{array}{c}\text { Aques } \\
\text { extract of } \\
\text { Parsley } \\
\text { leaves } 10 \%\end{array}$ \\
\hline $\begin{array}{l}\text { Peas:50g } \\
\text { Dicedpotatoes } \\
: 50 \mathrm{~g} \text { Diced } \\
\text { carrots:50g } \\
\text { Mayonnaise: } 2 \\
0 \mathrm{~g} \text { A pinch } \\
\text { of salt Pinch } \\
\text { of black } \\
\text { pepper. }\end{array}$ & $\begin{array}{l}\text { Peas:50g } \\
\text { Dicedpotatoes: } \\
50 \mathrm{~g} \text { Diced } \\
\text { carrots: } 50 \mathrm{~g} \\
\text { Mayonnaise: } 20 \\
\mathrm{~g} \text { A pinch of } \\
\text { salt Pinch of } \\
\text { black pepper. } \\
\text { Aques extract } \\
\text { of Parsley seeds } \\
5 \%\end{array}$ & $\begin{array}{l}\text { Peas:50g } \\
\text { Dicedpotatoes: } \\
\text { 50g Diced } \\
\text { carrots:50g } \\
\text { Mayonnaise: } 2 \\
\text { 0g A pinch of } \\
\text { salt Pinch of } \\
\text { black pepper. } \\
\text { Aques extract } \\
\text { of Parsley } \\
\text { leaves } 5 \%\end{array}$ & $\begin{array}{l}\text { Peas: } 50 \mathrm{~g} \\
\text { Dicedpotatoes: } \\
\text { 50g Diced } \\
\text { carrots:50g } \\
\text { Mayonnaise: } 20 \\
\mathrm{~g} \text { A pinch of } \\
\text { salt Pinch of } \\
\text { black } \\
\text { pepper. } \\
\text { Aques extract } \\
\text { of Parsley } \\
\text { seeds } 10 \%\end{array}$ & $\begin{array}{l}\text { Peas:50g } \\
\text { Dicedpotatoes } \\
: 50 \mathrm{~g} \text { Diced } \\
\text { carrots: } 50 \mathrm{~g} \\
\text { Mayonnaise: } 2 \\
0 \mathrm{~g} \text { A } \\
\text { pinch of salt } \\
\text { Pinch of black } \\
\text { pepper. } \\
\text { Aques extract } \\
\text { of Parsley } \\
\text { leaves } 10 \%\end{array}$ \\
\hline
\end{tabular}




\begin{tabular}{|c|c|c|c|c|}
\hline \multicolumn{5}{|c|}{ Tuna salad } \\
\hline $\begin{array}{c}\text { Aques } \\
\text { extract of } \\
\text { Parsley } 0 \%\end{array}$ & $\begin{array}{c}\text { Aques extract } \\
\text { of Parsley } \\
\text { seeds } 5 \%\end{array}$ & $\begin{array}{l}\text { Aques } \\
\text { extract of } \\
\text { Parsley } \\
\text { leaves5\% }\end{array}$ & $\begin{array}{c}\text { Aques extract } \\
\text { of Parsley } \\
\text { seeds } 10 \%\end{array}$ & $\begin{array}{c}\text { Aques extract } \\
\text { of Parsley } \\
\text { leaves } 10 \%\end{array}$ \\
\hline $\begin{array}{l}\text { Tuna }: 150 \mathrm{~g} \\
\text { Pickled:40g } \\
\text { Mayonnaise: } \\
30 \mathrm{~g}\end{array}$ & $\begin{array}{l}\text { Tuna }: 150 \mathrm{~g} \\
\text { Pickled:40g } \\
\text { Mayonnaise: } 3 \\
0 \mathrm{~g} \text { Aques } \\
\text { extract of } \\
\text { Parsley seeds } \\
5 \%\end{array}$ & $\begin{array}{l}\text { Tuna }: 150 \mathrm{~g} \\
\text { Pickled:40g } \\
\text { Mayonnaise:3 } \\
0 \mathrm{~g} \text { Aques } \\
\text { extract of } \\
\text { Parsley leaves } \\
5 \%\end{array}$ & $\begin{array}{l}\text { Tuna }: 150 \mathrm{~g} \\
\text { Pickled:40g } \\
\text { Mayonnaise: } 30 \\
\mathrm{~g} \text { Aques extract } \\
\text { of Parsley seeds } \\
10 \%\end{array}$ & $\begin{array}{l}\text { Tuna }: 150 \mathrm{~g} \\
\text { Pickled:40g } \\
\text { Mayonnaise: } 30 \mathrm{~g} \\
\text { Aques extract of } \\
\text { Parsley leaves } \\
10 \%\end{array}$ \\
\hline
\end{tabular}

\section{Sensory evaluation:}

The products supplemented with the aques extract of parsley seeds and leaves and their combination were evaluated for color, odor, texture, taste, and overall acceptability by ten (10) nutritionists stuff in the college of specific education, Damietta university. The evaluation was carried out according to the method of A.A.C.C.(2002).

\section{Statistical analysis:}

The obtained data were statistically analyzed using computer. The results were expressed as mean \pm standard deviation "S.D" and tested for significancy using one way analysis of variance "ANOVA" test to compare among groups of numerical (parametric) data followed by post-hoc tukey. P value $\leq 0.05$ was considered statistically significant, according to Armitage and Berry, (1987).

\section{RESULTS AND DISCUSSION}

Data in table (2) revealed that the mean value \pm SD of body weight gain of the positive control group (acute kidney stones) $\left(161.9 \pm 2.6^{\mathrm{b}}\right)$ decreased significantly in $(p<0.05)$, as compared to negative control group $\left(265.0 \pm 7.1^{\mathrm{a}}\right)$ .changes in body weight gain of all treated groups revealed no significant decrease in $(\mathrm{p}<0.05)$, as compared to the positive control group. 
Our results disagree with, Rezazad and Farokhi., (2014) who reported that, the body weight of the treated rats with parsley extract was significantly decreased compared with the positive control group.

Table(2): Effect of aquas extract of parsley seeds and leaves on initial body weight, final body weight and body weight gain of rats infected with kidney stones:

\begin{tabular}{l|c|c|c}
\hline & $\begin{array}{c}\text { Initial body } \\
\text { weight(gm) }\end{array}$ & $\begin{array}{c}\text { Final body } \\
\text { weight(gm) }\end{array}$ & BW-change (gm) \\
\hline Neg Control & $177.5 \pm 2.7^{\text {a }}$ & $265.0 \pm 7.1^{\text {a }}$ & $87.50 \pm 7.56^{\text {a }}$ \\
\hline Pos Control & $177.5 \pm 2.7^{\text {a }}$ & $161.9 \pm 2.6^{\mathrm{b}}$ & $-15.63 \pm 4.17^{\mathrm{b}}$ \\
\hline $\begin{array}{l}\text { Aquas } \\
\text { extract of } \\
5 \% \text { seeds }\end{array}$ & $177.5 \pm 2.7^{\mathrm{a}}$ & $161.9 \pm 2.6^{\mathrm{b}}$ & $-15.63 \pm 1.77^{\mathrm{b}}$ \\
\hline $\begin{array}{l}\text { Aquas } \\
\text { extract of } \\
5 \% \text { leaves }\end{array}$ & $177.5 \pm 2.7^{\mathrm{a}}$ & $163.1 \pm 2.6^{\mathrm{b}}$ & $-14.38 \pm 1.77^{\mathrm{b}}$ \\
\hline $\begin{array}{l}\text { Aquas } \\
\text { extract of } \\
10 \% \text { seeds }\end{array}$ & $177.5 \pm 2.7^{\mathrm{a}}$ & $161.3 \pm 2.3^{\mathrm{b}}$ & $-16.25 \pm 3.54^{\mathrm{b}}$ \\
\hline $\begin{array}{l}\text { Aquas } \\
\text { extract of } \\
10 \% \text { leaves }\end{array}$ & $177.5 \pm 2.7^{\mathrm{a}}$ & $161.3 \pm 2.3^{\mathrm{b}}$ & $-16.25 \pm 2.31^{\mathrm{b}}$ \\
\hline
\end{tabular}

Values are expressed as means \pm SD for 8 rats in each group.

Mean values in each column with same letters are not statistically different.

Least significant differences $(P<0.05)$.

Data in table (3) show the effect of the parsley seeds and leaves extracts on serum sodium $(\mathrm{mg} / \mathrm{dl})$, serum potassium $(\mathrm{mg} / \mathrm{dl})$, serum calcium $(\mathrm{mg} / \mathrm{dl})$ and serum chloride $(\mathrm{mg} / \mathrm{dl})$ of rats suffering from kidney stones. It could be observed that serum of (sodium, potassium ,calcium and chloride) $(\mathrm{mg} / \mathrm{dl})$ in the positive control group $\left(176.53 \pm 9.91^{\mathrm{a}}, 15.12 \pm 1.36^{\mathrm{a}}, 18.61 \pm .90^{\mathrm{a}}\right.$ and $141.06 \pm 7.70^{\mathrm{a}}$, respectively) the mean values of these parameters increased significantly $(\mathrm{p}<0.05)$, as compared to the negative control $\operatorname{group}\left(130.56 \pm 13.32^{\mathrm{c}}, 4.55 \pm .32^{\mathrm{e}}, 10.38 \pm .74^{\mathrm{d}}, \quad 98.20 \pm 8.28\right.$

,respectively). 
Concerning serum sodium $(\mathrm{mg} / \mathrm{dl})$, treated groups of rats revealed that significant decrease in serum sodium, as compared to the positive control group $(\mathrm{p}<0.05)$, with $(5 \%$ seeds, $10 \%$ seeds and $10 \%$ leaves $)$ extracts recorded serum sodium decrease amang positive control group, while rats treated with $5 \%$ leaves extract showed non- significant decrease as compared to the positive group, group of rats which was treated with $10 \%$ seeds extract recorded as the best result in serum sodium serum.

Concerning serum potassium $(\mathrm{mg} / \mathrm{dl})$, data showed significant decrease $(\mathrm{p}<0.05)$ in serum potassium amang the positive control group and all treated groups (5\% seeds, $5 \%$ leaves, $10 \%$ seeds and $10 \%$ leaves)extract. Treating rats with $(5 \%$ seeds or $10 \%$ seeds) extract recorded the best results in serum potassium.

Regarding serum calcium(mg/dl), data showed significant decrease in $(\mathrm{p}<0.05)$ in serum calcium amang the positive control group and all treated groups (5\% seeds, 5\% leaves, $10 \%$ seeds and 10\% leaves) extract, the best significant decrease in serum calcium showed in the group which treated with $10 \%$ seeds extract.

Regarding serum chloride(mg/dl), data showed significant decrease in Serum chloride between the positive control group and (10\% seeds) in $(\mathrm{p}<0.05)$. On the other hand, treated groups (5\% seeds, 5\% leaves and $10 \%$ leaves ) showed non- significant differences in this parameter, except the group which treated with $10 \%$ seeds extract in as compared to the positive group.

This finding are inagreement with Sunitha et al., (2012) who reported that the reduction of serum potassium due to diuresis of parsley. Also significant decrease in serum sodium in all treated groups. This may be due to the diuretic effect of parsley which is supported by concomitant decrease in serum potassium .

In this regard, Edward, (2015) showed significant decrease in serum calcium in all treated groups compared to positive control.

These findings are inagreement with Gumaih et al., (2017) indicated that significant decrease in serum sodium, serum potassium, serum calcium and serum chloride, as compared to the negative control group. 
Table (3): Effect of the aquas extract of parsley seeds and leaves on some minerals in serum of rats suffering from kidney stones.

\begin{tabular}{|c|c|c|c|c|}
\hline & $\begin{array}{c}\text { Serum } \\
\text { Sodium(mg/dl) } \\
\end{array}$ & \begin{tabular}{|c|} 
Serum Potassium \\
$(\mathrm{mg} / \mathrm{dl})$
\end{tabular} & $\begin{array}{c}\text { Serum Calcium } \\
(\mathrm{mg} / \mathrm{dl})\end{array}$ & \begin{tabular}{|c|} 
Serum Chloride \\
(mg/dl)
\end{tabular} \\
\hline Neg Control & $130.56 \pm 13.32^{c}$ & $4.55 \pm .32^{\mathrm{e}}$ & $10.38 \pm .74^{d}$ & $98.20 \pm 8.28^{b}$ \\
\hline Pos Control & $176.53 \pm 9.91^{\mathrm{a}}$ & $15.12 \pm 1.36^{\mathrm{a}}$ & $18.61 \pm .90^{\mathrm{a}}$ & $141.06 \pm 7.70^{\mathrm{a}}$ \\
\hline $\begin{array}{l}\text { Aquas extract } \\
\text { of } 5 \% \text { seeds }\end{array}$ & $154.61 \pm 19.52^{b}$ & $6.86 \pm .47^{d}$ & $13.86 \pm 1.10^{c}$ & $133.38 \pm 11.17^{a}$ \\
\hline $\begin{array}{l}\text { Aquas extract } \\
\text { of } 5 \% \text { leaves }\end{array}$ & $163.33 \pm 16.87^{\text {ab }}$ & $11.30 \pm 1.10^{b}$ & $16.59 \pm .49^{\mathrm{b}}$ & $139.25 \pm 13.59^{a}$ \\
\hline $\begin{array}{l}\text { Aquas extract } \\
\text { of } 10 \% \text { seeds }\end{array}$ & $147.81 \pm 7.52^{b c}$ & $6.38 \pm .34^{d}$ & $10.90 \pm .46^{\mathrm{d}}$ & $110.25 \pm 1.21^{b}$ \\
\hline $\begin{array}{l}\text { Aquas extract } \\
\text { of } 10 \% \text { leaves }\end{array}$ & $153.11 \pm 7.36^{b}$ & $8.66 \pm 1.12^{c}$ & $15.90 \pm 1.77^{b}$ & $133.89 \pm 11.30^{a}$ \\
\hline
\end{tabular}

Values are expressed as means + SD for 8 rats in each group.

Mean values in each column with same letters are not statistically different. Least significant differences $(P<0.05)$.

Data in table (4) show the Effect of the aquas extract of parsley seeds and leaves on kidney functions of rats suffering from kidney stones. it could be observed that, serum of (creatinine, uric acid and urea ) $(\mathrm{mg} / \mathrm{dl})$ in the positive control group $\left(2.03 \pm .14^{\mathrm{a}}, 2.04 \pm .02^{\mathrm{a}} \quad, 91.05 \pm 8.77^{\mathrm{a}}\right.$,respectively) increased significantly in $(\mathrm{p}<0.05)$, as compared to the negative control group

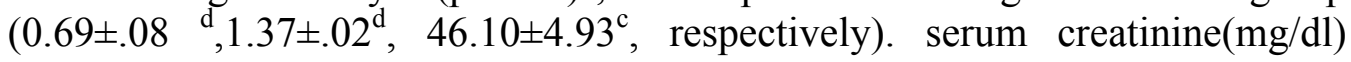
showed significant decrease in $(\mathrm{p}<0.05)$ in all treated groups $(5 \%$ seeds, $5 \%$ leaves, $10 \%$ seeds and $10 \%$ leaves) extracts. Treated group with $10 \%$ seeds recorded the best results in serum creatinine, because this group showed significant decrease $(\mathrm{p}<0.05)$ as compared to all treated groups. regarding, serum uric $\operatorname{acid}(\mathrm{mg} / \mathrm{dl})$ data showed significant decrease $(\mathrm{p}<0.05)$ amang the positive control group and all treated groups . Treated group with $10 \%$ seeds extract recorded the best results in serum uric acid, because this group showed the best significant decrease $(\mathrm{p}<0.05)$ as compared to all treated groups. Also, regarding serum urea $(\mathrm{mg} / \mathrm{dl})$ data showed significant decrease $(\mathrm{p}<0.05)$ in serum urea amang positive control and the group (5\% seeds and $10 \%$ seeds ). On the other hand, treated groups with (5\% leaves and 10\% leaves) showed non- significant differences as compared to the positive group. Treated group with $10 \%$ seeds extract recorded the best results in serum urea, because this group showed the best significant decrease in $(p<0.05)$ as compared to all treated groups. 
Ruckmani et al., (1998) found that the nephroprotective and antiurolithatic effects of cystone was found to be due to increased citrate concentration hence reduction of crystallization of calcium oxalate.

Also, Nair et al., (2006) reported that flavonoides have anti-inflammatory properties which, prevent the deleterious effects of toxic agents by modulation of inflammatory response.

In this respect, Martin, (2009) reported that ethylene glycol (EG) poisoning can lead to acute renal failure which is characterized by proximal tubular necrosis and an accumulation of $\mathrm{CaOx}$ monohydrate crystals in the urine and kidney tissues.

Table(4): Effect of the aquas extract of parsley seeds and leaves on kidney functions of rats suffering from kidney stones

\begin{tabular}{l|c|c|c}
\hline & $\begin{array}{c}\text { Serum Creatinine } \\
(\mathrm{mg} / \mathrm{dl})\end{array}$ & $\begin{array}{c}\text { Serum Uric acid } \\
(\mathrm{mg} / \mathrm{dl})\end{array}$ & $\begin{array}{c}\text { Serum Urea } \\
(\mathrm{mg} / \mathrm{dl})\end{array}$ \\
\hline Neg Control & $.69 \pm .08^{\mathrm{d}}$ & $1.37 \pm .02^{\mathrm{d}}$ & $46.10 \pm 4.93^{\mathrm{c}}$ \\
\hline Pos Control & $2.03 \pm .14^{\mathrm{a}}$ & $2.04 \pm .02^{\mathrm{a}}$ & $91.05 \pm 8.77^{\mathrm{a}}$ \\
\hline $\begin{array}{l}\text { Aquas extract of } \\
5 \% \text { seeds }\end{array}$ & $.96 \pm .12^{\mathrm{c}}$ & $1.67 \pm .02^{\mathrm{c}}$ & $67.22 \pm 5.09^{\mathrm{b}}$ \\
\hline $\begin{array}{l}\text { Aquas extract of } \\
5 \% \text { leaves }\end{array}$ & $1.64 \pm .13^{\mathrm{b}}$ & $1.89 \pm .06^{\mathrm{b}}$ & $81.69 \pm 8.51^{\mathrm{a}}$ \\
\hline $\begin{array}{l}\text { Aquas extract of } \\
10 \% \text { seeds }\end{array}$ & $.91 \pm .06^{\mathrm{c}}$ & $1.70 \pm .16^{\mathrm{c}}$ & $62.81 \pm 4.69^{\mathrm{b}}$ \\
\hline $\begin{array}{l}\text { Aquas extract of } \\
10 \% \text { leaves }\end{array}$ & $1.53 \pm .09^{\mathrm{b}}$ & $1.88 \pm .05^{\mathrm{b}}$ & $82.94 \pm 6.56^{\mathrm{a}}$ \\
\hline
\end{tabular}

Values are expressed as means + SD for 8 rats in each group.

Mean values in each column with same letters are not statistically different. Least significant differences $(P<0.05)$.

Data in table (5) show the effect of the aquas extract of parsley seeds and leaves on some minerals in urine of rats suffering from kidney stones. The results observed that, urine calcium and protein) $(\mathrm{mg} / 24 \mathrm{~h})$ in the positive control group $\left(19.74 \pm 1.03^{\mathrm{a}}\right.$

and $11.70 \pm .86^{\mathrm{a}}, \quad$ respectively) increased significantly in $(\mathrm{p}<0.05)$, as compared to the negative control group $\left(10.13 \pm .35^{\mathrm{e}}\right.$ and $5.29 \pm .35^{\mathrm{d}}$, respectively), regarding, urine calcium $(\mathrm{mg} / 24 \mathrm{~h})$ data showed significant decrease in $(\mathrm{p}<0.05)$ amang positive control and all treated groups. The best results in Urine Calcium was in the group treated with $10 \%$ seeds in $(\mathrm{p}<0.05)$ as compared to all groups. Also, according urine protein 
$(\mathrm{mg} / 24 \mathrm{~h})$ data showed significant decrease in $(\mathrm{p}<0.05)$ amang positive control and the group (5\% seeds, $10 \%$ seeds and $10 \%$ leaves) extract. On the other hand, treated group with 5\% leaves showed non- significant decrease as compared to the positive group. The best results in Urine Protein was in the groups treated with $(5 \%$ and $10 \%$ seeds $)$ in $(\mathrm{p}<0.05)$ as compared to all groups.

In this respect, Lemann et al., (1991) found that ethylene glycol administration increased urinary calcium level. It has been stated that hypercalciuria favors precipitation of calcium oxalate in urine.

This findings are in agreement with Moram,( 2016) observed that the effect of parsley on urinary calcium and found a significant decrease in urinary calcium in parsley group compared to positive control and this is consistent with our study

Table(5): Effect of the aquas extract of parsley seeds and leaves on some minerals in urine of rats suffering from kidney stones .

\begin{tabular}{l|c|c}
\hline & $\begin{array}{c}\text { Urine Calcium } \\
(\mathrm{mg} / 24 \mathrm{~h})\end{array}$ & Urine Protein (mg/24h) \\
\hline Neg Control & $10.13 \pm .35^{\mathrm{e}}$ & $5.29 \pm .35^{\mathrm{d}}$ \\
\hline Pos Control & $19.74 \pm 1.03^{\mathrm{a}}$ & $11.70 \pm .86^{\mathrm{a}}$ \\
\hline Treatment 5\% seeds & $14.08 \pm 1.30^{\mathrm{c}}$ & $7.64 \pm .67^{\mathrm{c}}$ \\
\hline Treatment 5\% leaves & $17.41 \pm .80^{\mathrm{b}}$ & $10.96 \pm 1.03^{\mathrm{a}}$ \\
\hline Treatment 10\% seeds & $12.11 \pm .91^{\mathrm{d}}$ & $7.63 \pm .50^{\mathrm{c}}$ \\
\hline Treatment 10\% leaves & $16.64 \pm .85^{\mathrm{b}}$ & $9.80 \pm .65^{\mathrm{b}}$ \\
\hline
\end{tabular}

Values are expressed as means + SD for 8 rats in each group.

Mean values in each column with same letters are not statistically different.

\section{Least significant differences $(P<0.05)$.}

Data in table (6) show the sensory evaluation to some food products, results showed a high degree of acceptance in the mean values for color, texture, odor, taste, general acceptability and total evaluation for the samples . It is noticed that decreased in degree of acceptance with increase of the ratio of aquas extract scores for color, texture, odor, taste and general acceptability. 


\section{Table(6): Sensory evaluation of some food products supplement with} parsley

Table(6-1): Sensory evaluation of ice cream with aquas extract of parsley

\begin{tabular}{|c|c|c|c|c|c|}
\hline $\begin{array}{c}\text { Properties } \\
\text { Treatments }\end{array}$ & $\begin{array}{c}\text { Color } \\
\text { (20 scores) }\end{array}$ & $\begin{array}{c}\text { Texture } \\
\text { (40 scores) }\end{array}$ & $\begin{array}{c}\text { Odor } \\
\text { (20 Scores) }\end{array}$ & $\begin{array}{c}\text { Taste } \\
\text { (20 Scores) }\end{array}$ & $\begin{array}{c}\text { General } \\
\text { acceptability } \\
\text { (20 Scores) }\end{array}$ \\
\hline $0 \%$ Parsley & $18.50 \pm 2.17^{\mathrm{a}}$ & $18.70 \pm 1.77^{\mathrm{a}}$ & $18.60 \pm 1.51^{\mathrm{a}}$ & $18.50 \pm 1.18^{\mathrm{a}}$ & $19.40 \pm .70^{\mathrm{a}}$ \\
$5 \%$ P seeds & $18.10 \pm 2.56^{\mathrm{a}}$ & $18.20 \pm 2.57^{\mathrm{a}}$ & $18.20 \pm 1.99^{\mathrm{a}}$ & $18.20 \pm 1.32^{\mathrm{a}}$ & $18.80 \pm .63^{\mathrm{a}}$ \\
$5 \%$ P leaves & $18.00 \pm 1.70^{\mathrm{a}}$ & $18.30 \pm 1.42^{\mathrm{a}}$ & $17.80 \pm 2.49^{\mathrm{a}}$ & $17.60 \pm 1.78^{\mathrm{ab}}$ & $18.40 \pm .84^{\mathrm{a}}$ \\
$10 \%$ P seeds & $17.70 \pm 1.57^{\mathrm{a}}$ & $17.70 \pm 1.16^{\mathrm{a}}$ & $17.60 \pm 1.90^{\mathrm{a}}$ & $17.00 \pm 1.76^{\mathrm{ab}}$ & $18.40 \pm .84^{\mathrm{a}}$ \\
$10 \%$ P leaves & $17.80 \pm 1.55^{\mathrm{a}}$ & $18.20 \pm 1.32^{\mathrm{a}}$ & $17.50 \pm 1.72^{\mathrm{a}}$ & $16.60 \pm 2.37^{\mathrm{b}}$ & $18.10 \pm 1.20^{\mathrm{a}}$ \\
\hline
\end{tabular}

Table(6-2):Sensory evaluation of egg plant salad with aquas extract of parsley

\begin{tabular}{|c|c|c|c|c|c|}
\hline Treatments & $\begin{array}{c}\text { Color } \\
\text { (20 scores) }\end{array}$ & $\begin{array}{c}\text { Texture } \\
\text { (40 scores) }\end{array}$ & $\begin{array}{c}\text { Odor } \\
\text { (20 Scores) }\end{array}$ & $\begin{array}{c}\text { Taste } \\
\text { (20 Scores) }\end{array}$ & $\begin{array}{c}\text { General } \\
\text { acceptability } \\
\text { (20 Scores) }\end{array}$ \\
\hline $0 \%$ Parsley & $19.50 \pm .71^{\mathrm{a}}$ & $19.50 \pm .97^{\mathrm{a}}$ & $19.20 \pm 1.23^{\mathrm{a}}$ & $19.60 \pm .52^{\mathrm{a}}$ & $18.80 \pm .63^{\mathrm{a}}$ \\
\hline $5 \%$ P seeds & $19.20 \pm .92^{\mathrm{a}}$ & $19.10 \pm 1.20^{\mathrm{a}}$ & $18.70 \pm 1.77^{\mathrm{a}}$ & $19.30 \pm .48^{\mathrm{a}}$ & $18.70 \pm .48^{\mathrm{a}}$ \\
\hline $5 \% \mathrm{P}$ leaves & $19.00 \pm 1.25^{\mathrm{a}}$ & $18.90 \pm 1.29^{\mathrm{a}}$ & $18.60 \pm 1.65^{\mathrm{a}}$ & $19.50 \pm .53^{\mathrm{a}}$ & $18.60 \pm .70^{\mathrm{a}}$ \\
\hline $10 \%$ P seeds & $19.00 \pm 1.49^{\mathrm{a}}$ & $18.80 \pm 2.10^{\mathrm{a}}$ & $18.60 \pm 1.90^{\mathrm{a}}$ & $18.20 \pm .42^{\mathrm{a}}$ & $18.80 \pm .42^{\mathrm{a}}$ \\
\hline $10 \% \mathrm{P}$ leaves & $19.00 \pm 1.89^{\mathrm{a}}$ & $18.70 \pm .82^{\mathrm{a}}$ & $18.60 \pm 1.90^{\mathrm{a}}$ & $18.40 \pm .52^{\mathrm{a}}$ & $18.30 \pm .67^{\mathrm{a}}$ \\
\hline
\end{tabular}

Table(6-3):Sensory evaluation of crème bavaroise with aquas extract of parsley

\begin{tabular}{|c|c|c|c|c|c|}
\hline $\begin{array}{c}\text { Properties } \\
\text { Treatments }\end{array}$ & $\begin{array}{c}\text { Color } \\
\text { (20 scores) }\end{array}$ & $\begin{array}{c}\text { Texture } \\
\text { (40 scores) }\end{array}$ & $\begin{array}{c}\text { Odor } \\
\text { (20 Scores) }\end{array}$ & $\begin{array}{c}\text { Taste } \\
\text { (20 Scores) }\end{array}$ & $\begin{array}{c}\text { General } \\
\text { acceptability } \\
\text { (20 Scores) }\end{array}$ \\
\hline $0 \%$ Parsley & $18.70 \pm 1.77^{\mathrm{a}}$ & $18.60 \pm 1.50^{\mathrm{a}}$ & $18.50 \pm 1.18^{\mathrm{a}}$ & $18.50 \pm 2.17^{\mathrm{a}}$ & $19.00 \pm .47^{\mathrm{a}}$ \\
$5 \%$ P seeds & $18.20 \pm 2.57^{\mathrm{a}}$ & $18.20 \pm 1.99^{\mathrm{a}}$ & $18.20 \pm 1.32^{\mathrm{a}}$ & $18.10 \pm 2.56^{\mathrm{a}}$ & $18.80 \pm .63^{\mathrm{ab}}$ \\
$5 \%$ P leaves & $18.30 \pm 1.42^{\mathrm{a}}$ & $17.80 \pm 2.49^{\mathrm{a}}$ & $17.60 \pm 1.78^{\mathrm{ab}}$ & $18.00 \pm 1.70^{\mathrm{a}}$ & $18.40 \pm .84^{\mathrm{ab}}$ \\
$10 \%$ P seeds & $17.70 \pm 1.16^{\mathrm{a}}$ & $17.60 \pm 1.90^{\mathrm{a}}$ & $17.00 \pm 1.76^{\mathrm{ab}}$ & $17.70 \pm 1.57^{\mathrm{a}}$ & $18.40 \pm .84^{\mathrm{ab}}$ \\
$10 \%$ P leaves & $18.20 \pm 1.32^{\mathrm{a}}$ & $17.50 \pm 1.72^{\mathrm{a}}$ & $16.60 \pm 2.37^{\mathrm{b}}$ & $17.80 \pm 1.55^{\mathrm{a}}$ & $18.10 \pm 1.20^{\mathrm{b}}$ \\
\hline
\end{tabular}

Table(6-4): Sensory evaluation of russian salad with aquas extract of parsley

\begin{tabular}{|c|c|c|c|c|c|}
\hline Properties & $\begin{array}{c}\text { Color } \\
\text { (20 scores) }\end{array}$ & $\begin{array}{c}\text { Texture } \\
\text { (40 scores) }\end{array}$ & $\begin{array}{c}\text { Odor } \\
\text { (20 Scores) }\end{array}$ & $\begin{array}{c}\text { Taste } \\
\text { (20 Scores) }\end{array}$ & $\begin{array}{c}\text { General } \\
\text { acceptability } \\
\text { (20 Scores) }\end{array}$ \\
\hline 0\% Parsley & $18.90 \pm 1.66^{\mathrm{a}}$ & $19.30 \pm .67^{\mathrm{a}}$ & $19.20 \pm .79^{\mathrm{a}}$ & $19.10 \pm .57^{\mathrm{a}}$ & $18.90 \pm 1.66^{\mathrm{a}}$ \\
$5 \%$ P seeds & $18.60 \pm 1.78^{\mathrm{a}}$ & $18.80 \pm .63^{\mathrm{a}}$ & $19.10 \pm .74^{\mathrm{a}}$ & $18.70 \pm .67^{\mathrm{a}}$ & $18.60 \pm 1.78^{\mathrm{a}}$ \\
$5 \%$ P leaves & $18.40 \pm 1.58^{\mathrm{a}}$ & $18.90 \pm .74^{\mathrm{a}}$ & $19.10 \pm .74^{\mathrm{a}}$ & $19.70 \pm 3.37^{\mathrm{a}}$ & $18.40 \pm 1.58^{\mathrm{a}}$ \\
$10 \%$ P seeds & $18.40 \pm 1.35^{\mathrm{a}}$ & $18.80 \pm .63^{\mathrm{a}}$ & $19.10 \pm .57^{\mathrm{a}}$ & $18.70 \pm .67^{\mathrm{a}}$ & $18.40 \pm 1.35^{\mathrm{a}}$ \\
$10 \%$ P leaves & $18.10 \pm 1.60^{\mathrm{a}}$ & $18.80 \pm .63^{\mathrm{a}}$ & $18.90 \pm .74^{\mathrm{a}}$ & $18.80 \pm .42^{\mathrm{a}}$ & $18.10 \pm 1.60^{\mathrm{a}}$ \\
\hline
\end{tabular}

Table(6-5):Sensory evaluation of tuna salad with aquas extract of parsley

\begin{tabular}{|c|c|c|c|c|c|}
\hline $\begin{array}{c}\text { Properties } \\
\text { Treatments }\end{array}$ & $\begin{array}{c}\text { Color } \\
\text { (20 scores) }\end{array}$ & $\begin{array}{c}\text { Texture } \\
\text { (40 scores) }\end{array}$ & $\begin{array}{c}\text { Odor } \\
\text { (20 Scores) }\end{array}$ & $\begin{array}{c}\text { Taste } \\
\text { (20 Scores) }\end{array}$ & $\begin{array}{c}\text { General } \\
\text { acceptability } \\
\text { (20 Scores) }\end{array}$ \\
\hline 0\% Parsley & $18.50 \pm 2.17^{\mathrm{a}}$ & $18.70 \pm 1.77^{\mathrm{a}}$ & $18.60 \pm 1.51^{\mathrm{a}}$ & $18.50 \pm 2.17^{\mathrm{a}}$ & $18.70 \pm 1.77^{\mathrm{a}}$ \\
$5 \%$ P seeds & $18.10 \pm 2.56^{\mathrm{a}}$ & $18.20 \pm 2.57^{\mathrm{a}}$ & $18.20 \pm 1.99^{\mathrm{a}}$ & $18.10 \pm 2.56^{\mathrm{a}}$ & $18.20 \pm 2.57^{\mathrm{a}}$ \\
$5 \% \mathrm{P}$ leaves & $18.00 \pm 1.70^{\mathrm{a}}$ & $18.30 \pm 1.42^{\mathrm{a}}$ & $17.80 \pm 2.49^{\mathrm{a}}$ & $18.00 \pm 1.70^{\mathrm{a}}$ & $18.30 \pm 1.42^{\mathrm{a}}$ \\
$10 \%$ P seeds & $17.70 \pm 1.57^{\mathrm{a}}$ & $17.70 \pm 1.16^{\mathrm{a}}$ & $17.60 \pm 1.90^{\mathrm{a}}$ & $17.70 \pm 1.57^{\mathrm{a}}$ & $17.70 \pm 1.16^{\mathrm{a}}$ \\
$10 \%$ P leaves & $17.80 \pm 1.55^{\mathrm{a}}$ & $18.20 \pm 1.32^{\mathrm{a}}$ & $17.50 \pm 1.72^{\mathrm{a}}$ & $17.80 \pm 1.55^{\mathrm{a}}$ & $18.20 \pm 1.32^{\mathrm{a}}$ \\
\hline
\end{tabular}




\section{Histopathological examination:}

\section{1- kidney :}

Microscopically, kidney of rat from negative control group revealed healthy and normal histological and glomerulinormal histological structure as no mineral sediments are observed in kidney section (photo. 1). In contrary, kidney of rat from positive control group showed calcium oxalate crystals (arrow) in a renal tubule, tubules and glomeruli showed no damage (photo. 2). Also, kidney of rat which treated with 5\% seeds extract group showed calcium oxalate crystals (arrow) in a renal tubule, tubules and glomeruli showed no damage (photo.3). Meanwhile, kidney of rat which treated with 5\% leaves extract group revealed calcium oxalate crystals (arrow) in a renal tubule, tubules and glomeruli showed no damage (photo.4). Moreover, kidney of rat which treated with $10 \%$ seeds extract group showed calcium oxalate crystals (arrow) in a renal tubule, tubules and glomeruli showed no damage (Photo.5). Also, kidney of rat which treated with $10 \%$ leaves extract group showed Calcium oxalate crystals (arrow) in a renal tubule, tubules and glomeruli showed no damage (Photo.6).

\section{2- Liver :}

Microscopically, liver of rat from negative control group revealed Hematoxylin and eosin (H\&E) staining of liver tissue showed normal histological apperance of liver in control rats (photo. 7). In contrary, liver of rat from positive control group showed hematoxylin and eosin (H\&E) staining of liver tissue showed normal histological apperance of liver in control rats (photo. 8) .Also, liver of rat from 5\% seeds group showed hematoxylin and eosin (H\&E) staining of liver tissue showed normal histological apperance of liver in control rats ( photo.9). Meanwhile, liver of rat from 5\% leaves group revealed hematoxylin and eosin (H\&E) staining of liver tissue showed normal histological apperance of liver in control rats (photo.10). Moreover, liver of rat from treatment $10 \%$ seeds group showed hematoxylin and eosin (H\&E) staining of liver tissue showed normal histological apperance of liver in control rats ( Photo.11). Also, liver of rat from 10\% leaves group showed hematoxylin and eosin (H\&E) staining of liver tissue showed normal histological apperance of liver in control rats (Photo.12). 


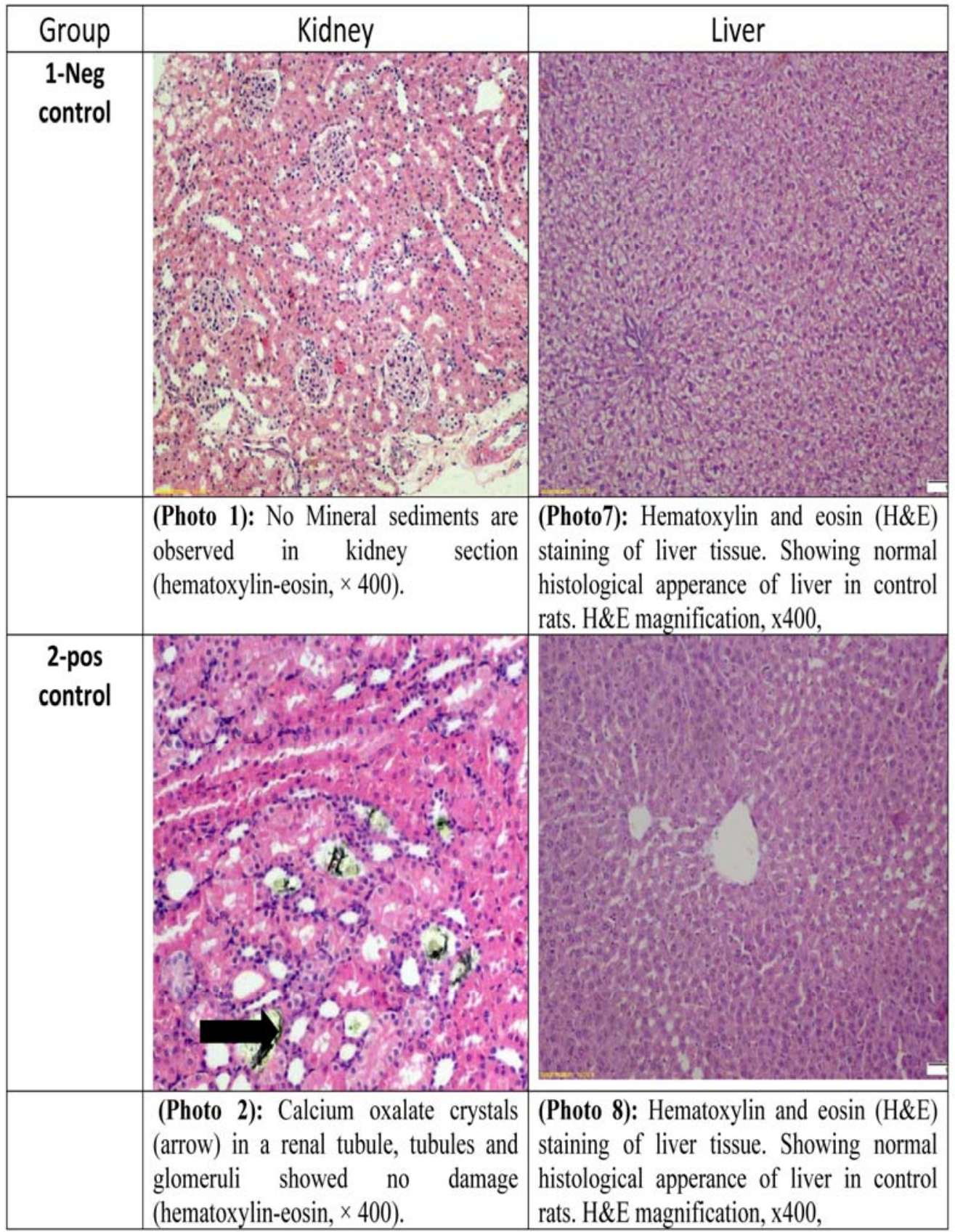




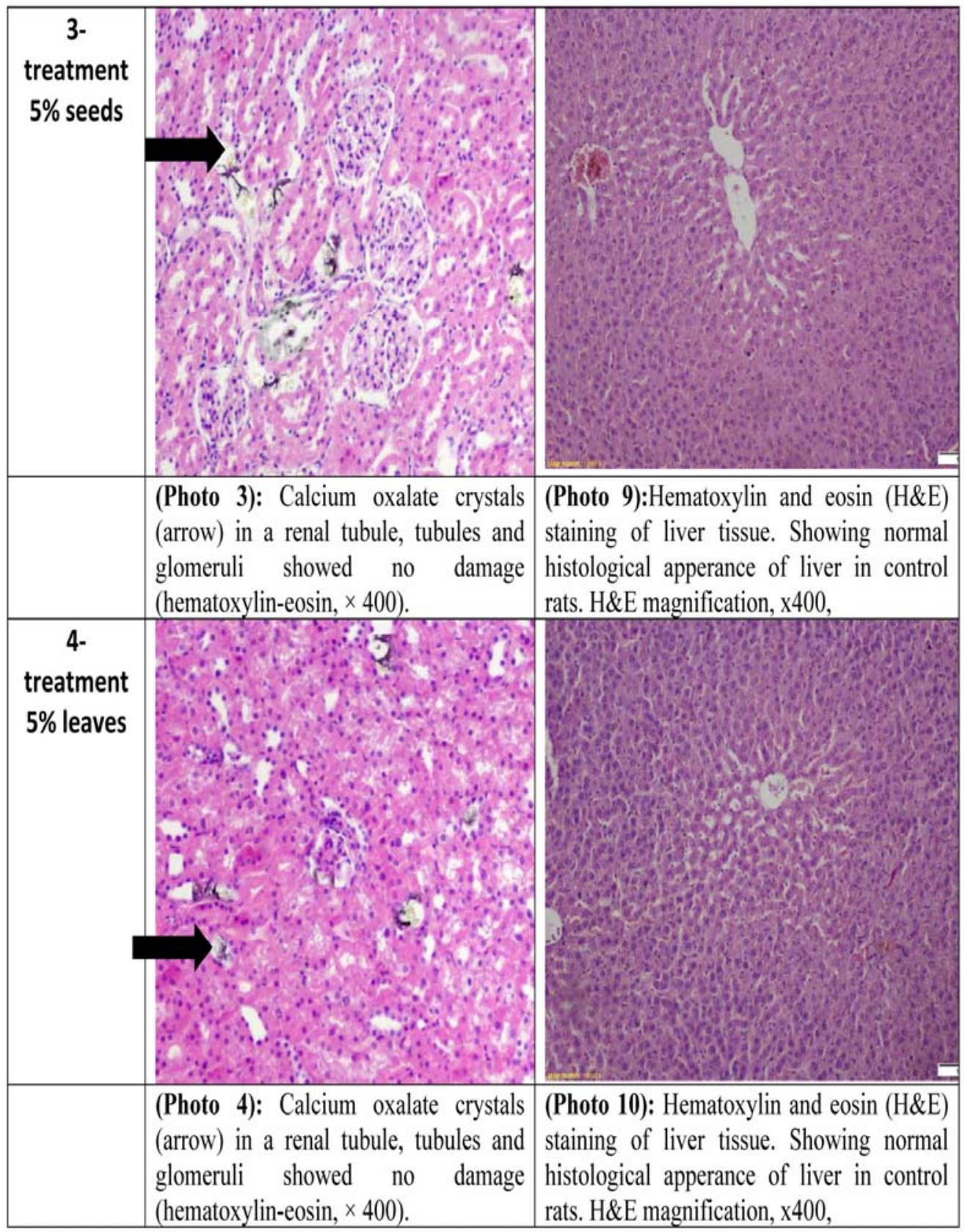




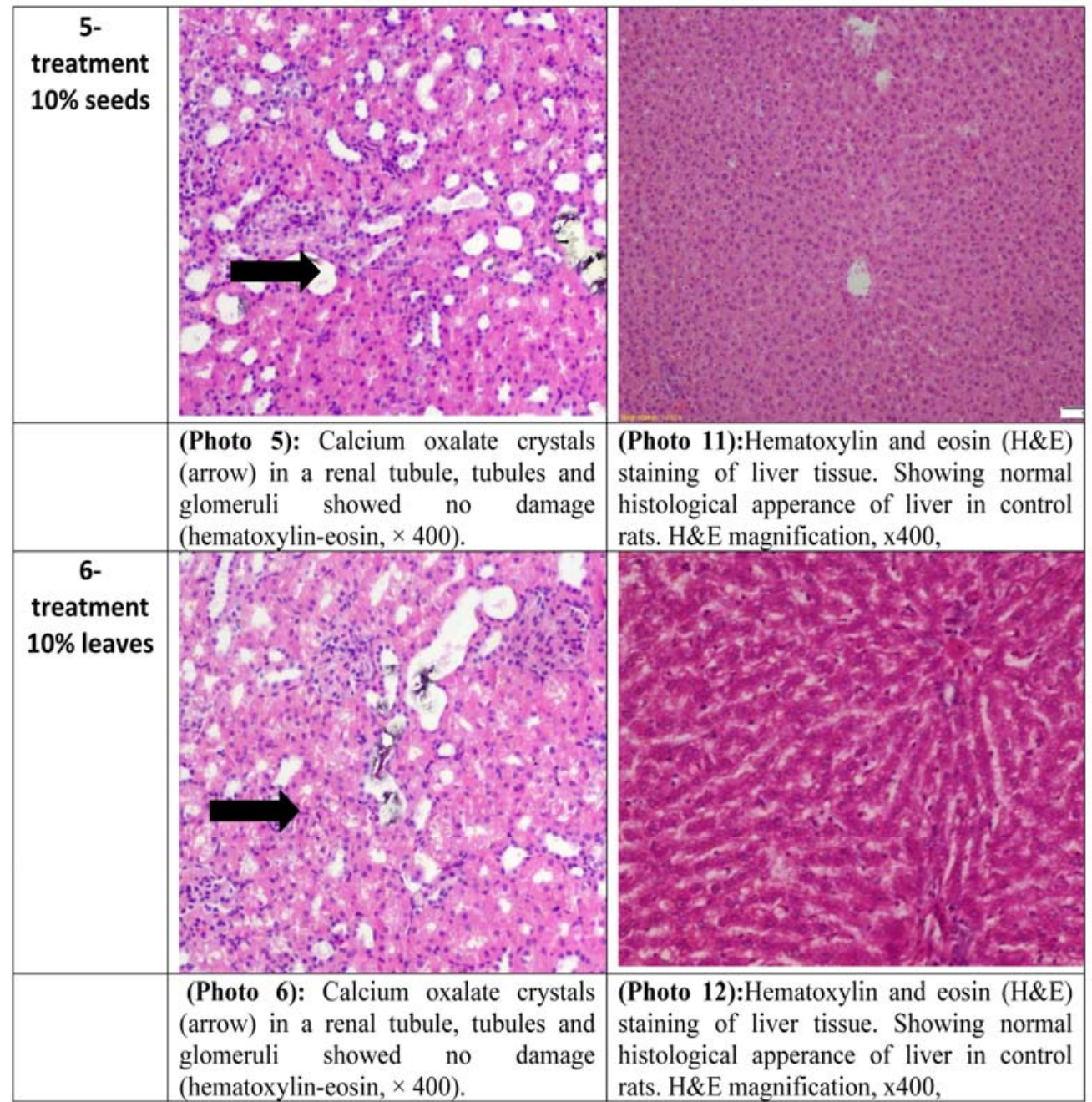

\section{CONCLUSION}

In conclusion, it is expected that this study resulted in improvement the tendencies toward petroselinum crispum as a useful and important medicinalplant with wide range of proven medicinal activity. The present study found that the administration of aquas extract of parsley seeds and leaves effectively decreased serum urea, creatinine, uric acid and electrolytes. Also, parsley has a nephroprotective and antiurolithiatic effects. According to sensory evaluation of all products revealed non- significant decrease in $(p<0.05)$ in color, texture, odor, taste and general acceptability. Concerning histopathological studies' results declared that parsley had good effects on kidney and liver. 


\section{REFERENCE}

A.A.C.C. (2002). Approved Method of American Association of Cereal Chemists, published by American Association of Cereal Chemists ,Ins. St. Paul, Minnesota, USA.

Alzergy,A.A.; Sitmo,M.S. and Hazawy, S.S.(2018). Role of Petroselinum crispum (Parsley) against gentamicin induced nephrotoxicity in albino rat. Faculty of Veterinary medicine. Omar Al Mukhtar University. AL Bayda,Libya. Nature and Science,16(5).

Andreasen, T.G. and Nielsen, H. (1992) . Ice cream and aerated desserts, in (R. Early, Ed.) Technology of dairy products, Blackie, London, pp 197220 .

Armitage, P. and Berry , G.(1987). Statistical Method in Medical Research . Blackwell, Oxford, UK: 93-213.

Azeez, S. and Parthasarathy, V.A. (2008). Parsley. In: Chemistry of Spices. V.A.Parthasarathy, B. Chempakam, T.J. Zachariah (Eds). CABI, 376400.

Bohmer, H.B.U.M. (1971). Micro- determination of creatinine . Clin . Chem. Acta, 32:81-85.

Chapman, D.G.; Gastilla, R. and Campbell, J.A.(1959).Evaluation of protein in food 1-A method for the determination of protein efficiency ratio. Can . J. Biochem . Physiol, 37:679-686.

Devi, K.S.; Damayanti, M.; Velmurugan, D. and Singh, N.R. (2015). Analysis of kidney stones by PXRD and evaluation of the antiurolithic potential of coix lacryma joba. Int. J. Sci. Res. Publ ,5(7): 1-5.

Dorman, H.J.; Lantto,T.A.; Raasmaja, A. and Hiltunen ,R. (2011). Antioxidant, pro-oxidant and cytotoxic properties of parsley, Food Function , 2 (6): 328-337.

Drury,R.A.and Wallington, E.A.(1980).Carton's Histological Technique .5 th ed. Oxford University.

Edward. (2015). 11 Foods high in calcium. Edward Group DC, NP, DACBCN, DABFM. ethylene-glycol induced urolithiasis in rats. Int. J. Drug. Dev. Res, 3 (1): 273- 280. 
European Food Safety Authority .(2010). Health claims related to various European Urology Supplements, 9(12):802-806.

Fan, J.; Glass, M.A. and Chandhoke, P.S. (1999) . Impact ofammonium chloride administration on a rat ethylene glycol urolithiasis model. Sca Microsc Int , 13: 299-306.

Fossati, P.; Principe, L. and Berti, G. (1980). Enzymatic colorimetric method of determination of uric acid in serum . Clin Chem, 26(2): 227-273.

Gumaih, H.; Al-Yousofy, F., Ibrahim, H.; Ali, S. and Alasbahy, A . (2017). Evaluation of ethanolic seed extract of parsley on ethylene glycol induced calcium oxalate, experimental model. Int J Sci Res ,6: 16831688.

Hadjzadeh, M.; Khoei ,A.; Hadjzadeh, Z. and Parizady, M. (2007) • Ethanolic Extract of Nigella Sativa L Seeds on Ethylene Glycol-Induced Kidney Calculi in Rats. Urol J.4:86-90.

Kreydiyyeh ,S and Usta ,J .(2002). Diuretic effect and mechanism of action of parsley, Journal of Ethnopharmacology, 79(3): 353-357.

Lemann, J.; Worcestor, E. and Gray, R .(1991). Hypercalciuria and stones .Am J Kidney Dis, 27:839.

Martin, K.M.c. (2009). Are calcium oxalate crystals involved in the mechanism of acute renal failure in ethylene glycol poisoning.Clin Toxicol, 47(9): 859-869.

Meyer, J. (1998). Authentic Hungarian Heirloon Recipes Cookbook, ed. 2. Meyer \& Assoc. ISBN 0-9665062-0-0.

Moe, O.W. (2006). Kidney stones: pathophysiology and medical management .Lancet, 367:333-344.

Moram, G.S. (2016) . Evaluation of anti-urolithiatic effect of aqueous extract of parsley (petroselinum sativum) using ethylene glycol-induced renal calculi.Wor J Pharmace Res, 5(2):1721-1735. 
Nair, M.P. ; Mahajan, S. ; Reynolds, J.L. ; Aalinkeel,R. ; Nair,H. ; Schwartz, S.A. and Kandaswami, C. (2006). The flavonoid quercetin inhibits proinflammatory cytokine (tumor necrosis factor alpha) gene expression in normal peripheral blood mononuclear cells via modulation of the NF-kappa beta system. Clin. Vaccine. Immunol, 13(3): 319-328.

Papay, Z.F.; Kosa, A.; Boldizsar,I.; Ruszkai,A.; Balogh, E. and Antal,I. ( 2012). Pharmaceutical and formulation aspects of Petroselinum crispum extract. Acta Pharmaceutica Hungarica, 82(1): 3-14.

Patton, C.J.and Crouch, S.R. (1977). Enzymatic colorimetric method of determination of urea in serum . Anal . Chem.,49:464.

Reeves PG; Nielsen FH and Fahmy GG (1993): AIN-93. Purified diets for laboratory rodents: Final report of the American Institute of Nutrition adhocwriling committee on the reformulation of the AIN-76 A Rodent diet. J. Nutrition, 123: 1939-151.

Rezazad, M . and Farokhi, F. (2014). Protective effect of Petroselinum crispum extract in abortion using prostadininduced renal dysfunction in female rats, Department of Biology, Urmia University, Urmia, I.R. Iran ,AJP, Vol. 4, No.5.

Ruckmani,K. ; Kavimani, S. and Anandan, R. B. (1998) . Effect of Moringa oleifera Lam On Paracetamol - induced hepatotoxicity. Indian. J Pharmaceutical. Sci, 60: 33-35.

Saba,N,H (2001) . Cooking, Science and Art . Dar El Maaref ,2001.

Saeidi, J.M.; Bozorgi, H.; Zendehdel, A. and Mehrzad, J. (2012). Therapeutic effects of aqueous extracts of Petroselinum sativum on ethylene glycol-induced kidney calculi in rats.Urology Journal, 9(1): 361-366.

Sarwar, S.; Ayyub, M. A. ; Rezgui, M.; Nisar, S. and Jilani, M. I. (2016) . Parsley: A review of habitat, phytochemistry, ethnopharmacology and biological activities, International Journal of Chemical and Biochemical Sciences ,ISSN 2226-9614. 
Sheehan , D. and Harpchak , B. (1980). Phory and bractec histoechnology .2 nd ed. Battle - Press, Ohio.

Soundararajan, P. ; Mahesh, R. T .; Ramesh, T. and Begum, V.H.(2006). Effect of Aerva lanata on calcium oxalate urolithiasis in rats . Indian J. Exp. Biol, 44 : 981-986.

Sunitha, J.; Asha, S. and Taju, G. (2012) . Protective effect of Spirulinaof ethylene glycol induced urolithiasis in rats. Int.Res.J.Pharma, 3(5):444448.

Wahba N. ; Ahmed A. and Ebraheim Z. (2009). Antimicrobial Effects of Pepper, Parsley, and Dill and Their Roles in the Microbiological Quality Enhancement of Traditional Egyptian Kareish Cheese. Foodborne Pathog Dis. Nov.

Werness, P.G.; Brown, C.M.; Smith, L.H. and Finlayson, B. (1985). EQUIL 2: A basic computer program for the calculation of urinary saturation. $\mathrm{J}$ Urol 134: 1242-1244.

Zahid, H.; Bawazir, A. S. and Naser,R. (2013). Plant based native therapy for the treatment of Kidney stones in Aurangabad (M.S).J. Pharmaco .Phytochem,1(6):189-193. 


\section{ملخص البحث}

تأثير مستخلص البقدونس على فئران التجارب المصابة بحصوات الكلى واستخدامه

\section{لعمل بعض المنتجات الغذائية}

البقدونس مصدر طبيعي غني بمضادات الأكسدة ـ تهدف الدراسة الحالية إلى دراسة تأثنر المستخلص المائي للبقدونس على فئران التجارب المصابة بحصوات الكلى وإمكانية استخدامه لعمل بعض المنتجات الغذائية. نم دراسة التحليل الحيوى الكميائى والفحص الهستوباثولوجي باستخدام هـ فأر

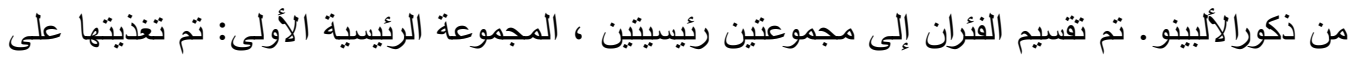

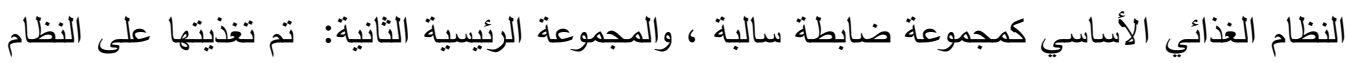

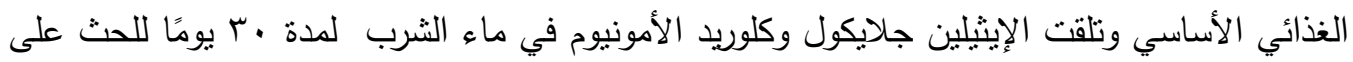

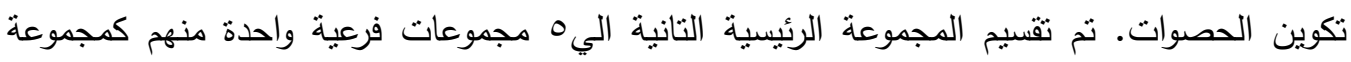

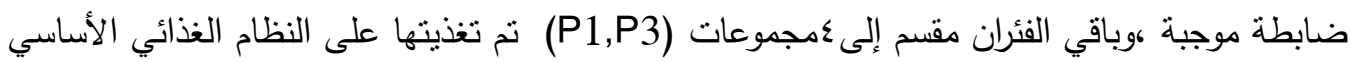

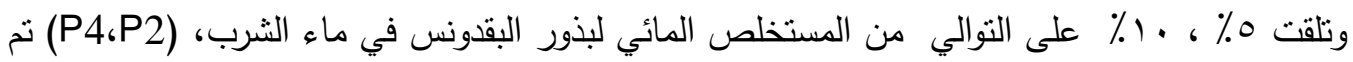

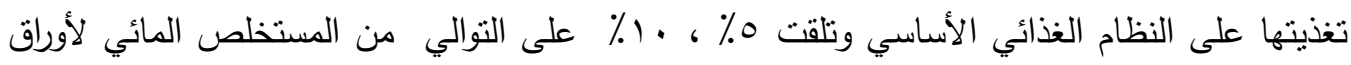
البقدونس في ماء الثرب ـ وتم إعداد ه منتجات باستخدام المستخلص المائي لبذور وأوراق البقدونس.

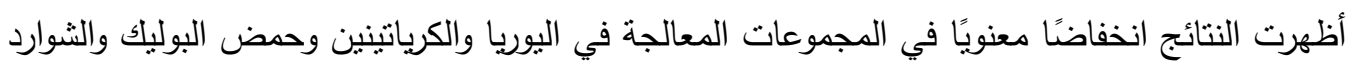

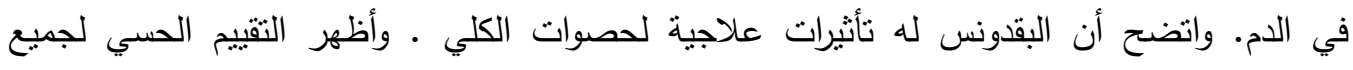
المنتجات انخفاض غير معنوي (0.05 p p في اللون والقوام والرائحة والطعم والمظهر العام ـ وأثنارت النتائج الهستوباثولوجية إلى وجود تأثثرات جيدة في نسيج الكلى والكبد.

الكلمات الرئيسية: بذور البقدونس - حصوات الكلي - الإيثلين جلايكول - كلوريد الأمونيوم وظائف الكلى - التقييم الحسي - إنزيمات الأكسدة - الفحص الهيستوباثولوجي - فئران التجارب. 